\title{
Quantifying the seawater sulfate concentration in the Ediacaran Shuram Excursion
}

\author{
YIXIN CUI ${ }^{1}$, BING SHEN $^{1}$
}

${ }^{1}$ Key Laboratory of Orogenic Belts and Crustal Evolution, MOE \& School of Earth and Space Sciences, Peking University, Beijing 100871, P. R. China;

cuiyixin@pku.edu.cn

The Ediacaran Period (635-541 Ma) witnessed the diversification of multicellular organisms and the oxygenation in the ocean. The Ediacaran oxidation was evidenced by the largest negative carbonate carbon isotope $\left(\delta^{13} \mathrm{C}_{\text {carb }}\right)$ excursion $(>-10 \%$ o), i.e. the Shuram Excursion (SE), which has been interpreted as the massive oxidation of dissolved organic carbon (DOC) in the deep ocean. However, this interpretation has been challenged by insufficient oxidants in the surface Earth. In addition, it remains unclear the level of atmospheric $\mathrm{O}_{2}$ level and seawater sulfate concentration. In this study, we analyzed carbonate carbon isotope $\left(\delta^{13} \mathrm{C}_{\mathrm{carb}}\right)$, carbonate associated iron $\left(\mathrm{Fe}_{\mathrm{carb}}\right)$, pyrite content ([pyrite]) and pyrite sulfur isotope $\left(\delta^{34} S_{\text {pyrtie }}\right)$ of samples from the Daotuo (DTZK) and Jiulongwan (JLW) drillcore/section. In both sections, SE is associated with an increase of [pyrite] and a decrease of $\delta^{34} S_{\text {pyrtie. }}$ We developed a diffusion-advection-reaction (DAR) model to simulate the process of pyrite formation in porewater. The modeling results indicate that the increase of [pyrite] and the decrease of $\delta^{34} S_{\text {pyrtie }}$ requires the increase of seawater sulfate concentration and the increase of oxygen fugacity in the seafloor. The seafloor oxidation is also supported by the drop of $\mathrm{Fe}_{\mathrm{carb}}$ in the SE. 